\title{
WATER-YIELD RELATIONSHIPS OF DEFICIT IRRIGATED TOMATO (LYCOPERSICON LYCOPERSICUM L. VAR. HAZAR F1)
}

\author{
AYAS, S. \\ Yenisehir İbrahim Orhan Vocational School, Uludag University \\ Iznik Way 2. km Yenisehir, Bursa, Turkey \\ (e-mail: serayas@uludag.edu.tr; phone:+90-224-773-6069; fax:+90-224-773-6041)
}

(Received 13 $3^{\text {th }}$ Mar 2019; accepted $3^{\text {rd }}$ May 2019)

\begin{abstract}
This trial was realized in the greenhouses of Uludag University Yenisehir Vocational School in Bursa province of Turkey between 2009 and 2010 to investigate effects of water deficit on yield and quality parameters of tomato during four crop growth stages. In this trial, fourteen irrigation treatments in four growth periods (vegetative, flowering, yield formation and ripening) of tomato (Lycopersicon lycopersicum L. var. Hazar F1) were constituted and the yield and quality parameters found from these treatments were evaluated. The layout of the experiment was a completely randomized block design with three replications for each of the fourteen irrigation treatments tested. According to the content of the treatments, the irrigation amount water applied to the plants varied between 0 and $554 \mathrm{~mm}$ in the first year, and between 0 and $556 \mathrm{~mm}$ in the second year. Water consumption of tomato in the first year ranged between 300 and $725 \mathrm{~mm}$ and in the second year ranged between 340 and $746 \mathrm{~mm}$. Yield, fruit weight, diameter, height and dry matter ratio were determined statistically significant. In 2009 and 2010 years, the maximum yield were found as $92.2 \mathrm{t} \mathrm{ha}^{-1}$ and $93.4 \mathrm{t} \mathrm{ha}^{-1}$ in $\mathrm{V}_{100} \mathrm{~F}_{100} \mathrm{Y}_{100} \mathrm{R}_{100}$ treatments, while the minimum yield were found as $2.0 \mathrm{tha}^{-1}$ and $4.0 \mathrm{ha}^{-1}$ in the $\mathrm{V}_{0} \mathrm{~F}_{0} \mathrm{Y}_{0} \mathrm{R}_{0}$ treatments, respectively. Water- yield relationship factors $\left(\mathrm{k}_{\mathrm{y}}\right)$ in 2009 and 2010 years were found as 1.05 and 1.06, respectively. The maximum WUE and IWUE values were obtained from vegetative and ripening periods. Vegetative and ripening periods may be suggested as the maximum efficient irrigation periods for the tomato applied with drip irrigation under unheated greenhouse conditions.
\end{abstract}

Keywords: tomato, deficit irrigation, WUE and IWUE values, yield and quality parameters of tomato, irrigation planning

\section{Introduction}

Decreases in water resources together with increasing impacts of global warming and climate changes and increasing demands of increasing population make effective utilization of water resources a must. Increasing demands of sectors also deplete the ground water resources, pollute water ecosystems and developing new water resources is getting more and more expensive each day. Since about $75 \%$ of water resources of Turkey is allocated for agricultural purposes, effective water utilization and water saving in irrigation are the most critical issues to be considered. Pressurized piped systems and especially drip irrigation should be widespread for effective water utilization in agriculture (Cakmak and Gokalp, 2011).

Van Straten et al. (2010) stated that the greenhousing is worldwide the fastest growing sector of all agricultural production activities. There are two essential causes for this. First, the plant grows in greenhouse differently from the external environment, in this way supplying in a sort of way of abri from the flat-out effect of the exterior air conditions. This allows the production of crops at that specific place. Second, the greenhouse allows to be produced of many crops. Thus, grower allows the farming to come true as desired. It also offers advantages such as higher crop yield, longer production period, better quality and less use of chemicals. The output unit of area in greenhouses is much higher than that in field agriculture. This situation permits the 
grower to direct the farming in a desirable aspect. It causes to higher crop yield, extended production period, better quality and less use of chemicals. The value added per unit surface area in greenhouse crops is much higher than that in field agriculture.

China, India are United States are the world's three biggest tomato producers with 57, 19, 15 million tons, respectively. United States is the largest tomato exporting country. Turkey is one of the significant tomato producer with Turkey 12750000 tons (fourthly in the world) in the world (FAOSTAT, 2017).

Papadopoulos (1992) pointed out the tomato is a major vegetable that has reached immense demand over the last hundred years. Tomato contains vitamins of $\mathrm{A}$ and $\mathrm{C}$ and is very useful for human heath. Tomato fruit is the best source of lycopene and lycopene is a cancer hampering antioxidant. Hence, tomato is very important in developed countries and its production is production is being tried to increase. Greenhouse cultivation is the optimum option for tomato producer because of higher quality of tomato. In addition, the crop is protected from insect, disease and pest. Moreover, the size of all fruit stays uniform because of optimum environment. Water is vital input for tomato to remain alive in greenhouse. Water is saved by the drip irrigation and plant gives better yield and quality.

Sezen (2005) found that surface irrigation is not suggested due to low irrigation efficiency originated from salinity and drainage problems in irrigated areas. From a different viewpoint, traditional irrigation systems where excess water inputs and poor drainage occur, cause environmental problems such as salinity and water logging. In irrigation methods where irrigation water is used efficiently do not have the problems of conventional irrigation methods (Buyukcangaz et al., 2007). Thus, the use of less water consuming irrigation methods is of great importance with regard to irrigation planning (Anonymous, 2005). The objective of irrigation planning is to prevent the soil moisture level falling below the critical line for a specific soil and crop condition. This may enable to avoid the harmful effect of water stress by means of estimating the earliest date (Ritchie and Johnson, 1990).

Irrigation planning with drip irrigation relies on approaches connected with evapotranspiration estimations (Bar-Yosef and Sagiv, 1982; McNeeish et al., 1985; Clough et al., 1990; Hartz, 1993) and permissible soil-water depletion (Bogle et al., 1989). $K y$ represents the declines in the yield as a result of each deficit level in water consumption. $K y$ values usually difficult to create accurately. $K y$ values are affected by regional conditions, soil properties, crop physiology and cultural practices. A suggested $K y$ value for irrigation planning must be high enough to avoid the water stress caused by the needs and specific local situations. It remains low enough for effective water management (Yuan et al., 2003). Some studies have been realized to investigate the effect of deficient irrigation on tomato. The purposes of this experiment were to obtain a prospectus for tomato growers and to determine drip irrigated tomato response to deficit irrigation regimes in Bursa conditions.

\section{Materials and methods}

The study was realized in Yenisehir Vocational School, Bursa of Turkey in 2009 and 2010 years. For practical purposes, plastic greenhouse $(8 \mathrm{~m} \mathrm{x} 40 \mathrm{~m})$ was used. In the study place, wintertimes are cold and summertimes are hot. The average annual rainfall and temperature values for the region where the greenhouse experiments were made in 2009 and 2010 were $531.3-804.4 \mathrm{~mm}$ and $13.3-14.6{ }^{\circ} \mathrm{C}$, respectively. While the average 
minimum temperature for 2009 and 2010 were -3.6 - (5.9) ${ }^{\circ} \mathrm{C}$ between January and December, the average maximum temperature in August was measured as 30.6 and $34.6{ }^{\circ} \mathrm{C}$ (Anonymous, 2011a). Maximum and minimum temperature values in greenhouse during the plant growing period (92 days) were $38-38{ }^{\circ} \mathrm{C}$ and $0.9-1.3{ }^{\circ} \mathrm{C}$, respectively in 2009-2010 years (Figs. 1 and 2). The highest and lowest relative humidity values in greenhouse in 2009 and 2010 years were found as $88-87 \%$ and 39$39 \%$, respectively (Fig. 3). In addition, the highest and lowest radiation values in greenhouse in 2009-2010 years were measured as $1974-1542 \mathrm{~W} / \mathrm{m}^{2}$ and $335-139 \mathrm{~W} / \mathrm{m}^{2}$, respectively (Fig. 4) (Anonymous, 2011b).

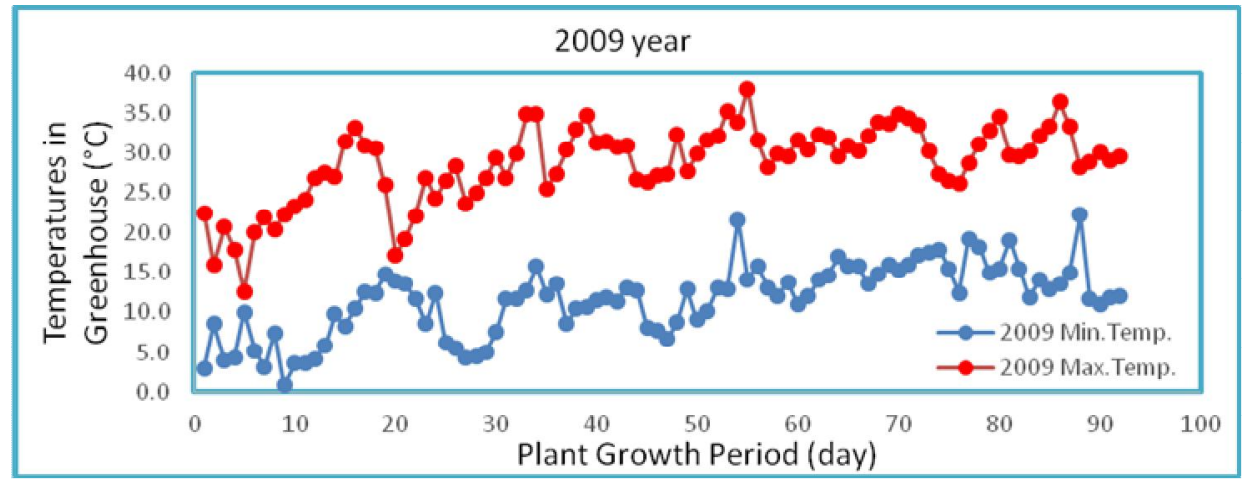

Figure 1. Temperatures in greenhouse during the plant growth period in 2009 year

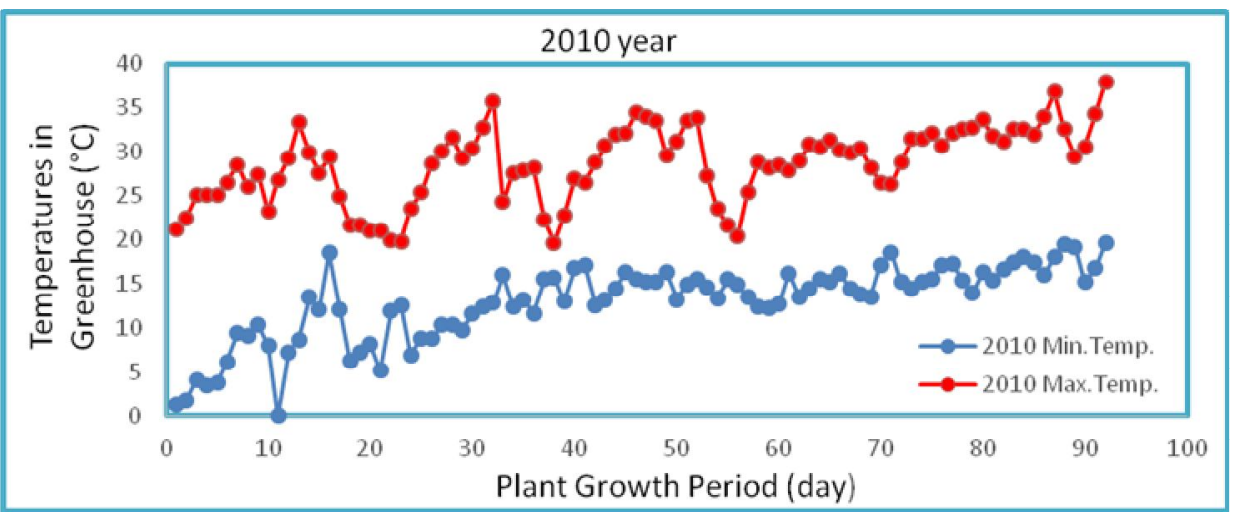

Figure 2. Temperatures in greenhouse during the plant growth period in 2010 year

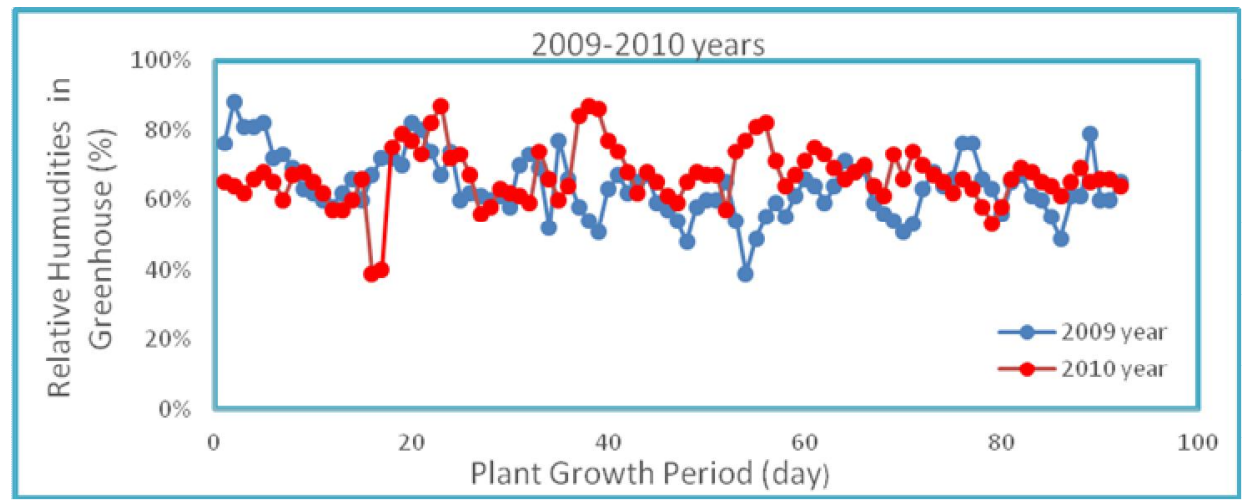

Figure 3. Relative humidities in greenhouse during the plant growth period in 2009-2010 years 


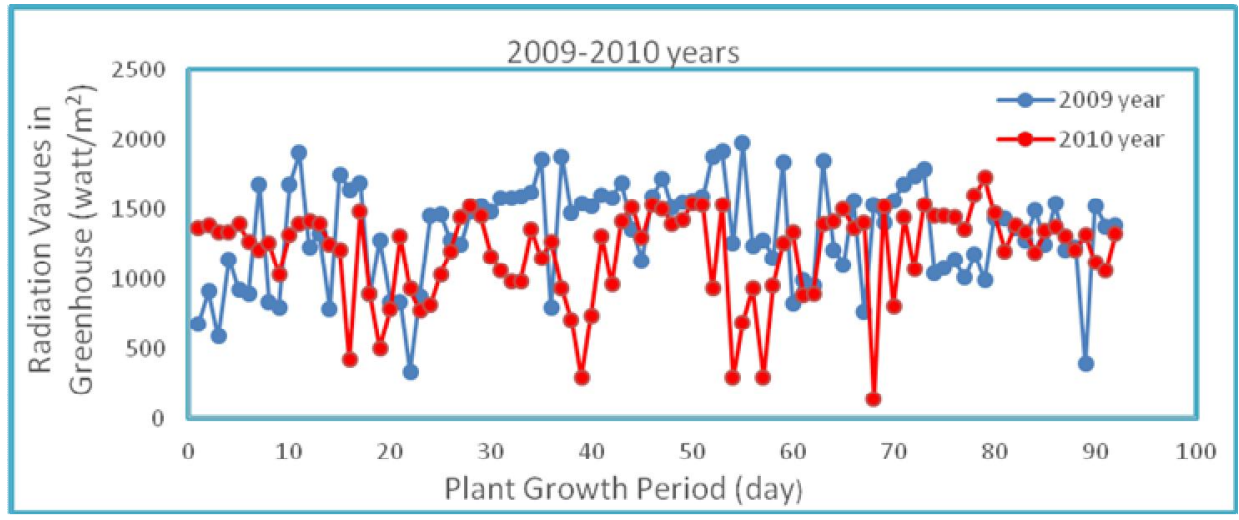

Figure 4. Radiation values in greenhouse during the plant growth period in 2009-2010 years

The soil of study place was sandy clay and $\mathrm{pH}$ value of soil ranged between 7.86 and 8.05. The specific features of the soil are given in Table 1.

Table 1. Some specific properties of the experimental soil

\begin{tabular}{|c|c|c|c|c|c|c|c|c|}
\hline $\begin{array}{l}\text { Soil depth } \\
\text { (cm) }\end{array}$ & Soil type & \begin{tabular}{|c} 
Unit weight \\
$\left(\mathrm{g} / \mathrm{cm}^{3}\right)$
\end{tabular} & $\begin{array}{c}\text { Field } \\
\text { capacity }(\%)\end{array}$ & \begin{tabular}{|c|} 
Wilting \\
point $(\%)$
\end{tabular} & $\mathbf{p H}$ & $\begin{array}{c}\text { Total salt } \\
\text { (\%) }\end{array}$ & $\begin{array}{c}\mathrm{CaCO}_{3} \\
(\%)\end{array}$ & $\begin{array}{c}\text { Organic } \\
\text { matter }(\%)\end{array}$ \\
\hline $0-30$ & $\mathrm{SL}$ & 1.34 & 29.73 & 21.74 & 7.99 & 0.037 & 16.5 & 2.92 \\
\hline $30-60$ & SL & 1.37 & 27.26 & 19.37 & 8.04 & 0.031 & 29.5 & 1.39 \\
\hline $60-90$ & SL & 1.58 & 33.92 & 23.72 & 7.86 & 0.034 & 31.5 & 1.08 \\
\hline $90-120$ & SL & 1.50 & 36.30 & 27.73 & 8.05 & 0.032 & 33.0 & 0.94 \\
\hline
\end{tabular}

SL: sandy loam

Hazar F1 variety was used in the study. Hazar F1 is a mid-early type and its fruits are around 15-25 g. Hazar F1 has a strong plant structure. The fruits of Hazar F1 are oval, bright, charming and are resistant to waiting and transporting. This variety has a wide adaptability and high efficiency. In addition, this variety is tolerant to early leaf blight. In the experimental area, an irrigation well was utilized as the source and the water was of the class $\mathrm{C}_{1} \mathrm{~S}_{1}$ after the analysis done. NPK 15-15-15 fertilizer was sprinkled on the soil by hand before planting the seedlings as bottom fertilizer. The application depth of the fertilizer ranged from 15 to $20 \mathrm{~cm}$ depending on the soil structure and the root depth of the plant grown. NPK 15-15-15 fertilizer was utilized to trial plots while the tomatoes were being planted, and $750 \mathrm{~kg}$ of NPK 15-15-15 fertilizer per hectares were utilized. The urea form of the nitrogen was applied to the plots together with the irrigation water. The first manure was applied as $250 \mathrm{~kg} / \mathrm{ha}(\% 46 \mathrm{~N})$ in the flowering stage and the second fertilizer was utilized as $250 \mathrm{~kg} / \mathrm{ha}$ in yield formation stage together with the irrigation water. Furthermore, in 2009 and 2010 years, $250 \mathrm{~kg}$ of magnesium nitrate manure per hectares $(11-0-0+16 \mathrm{MgO}-$ Nitrogen $\% 11$ and $\mathrm{MgO} \% 16)$ were used in the flowering and early yield formation stages to support the generative development.

The experimental blocks were formed with three replications and 14 trial treatments were randomly scattered. The size of the experimental plots was $4 \mathrm{~m}^{2}(2.0 \mathrm{~m} \times 2.0 \mathrm{~m})$. The distances between the plots were $0.80 \mathrm{~m}$ and blocks were placed with $1.5 \mathrm{~m}$ distances. The tomato seeds were sown in viyols on 01 April 2009 and on 04 April 2010 in the experimental years. The tomato seedlings were transplanted to the plots on 02 
May 2009 and on 05 May 2010. The seedlings were grown with $50 \mathrm{~cm}$ intervals on the same row and with $50 \mathrm{~cm}$ intervals between the plant lines. Into each plot, 25 plants were planted.

Some quality parameters of tomato are yield, fruit weight, diameter, height and dry matter ratio. The fruit weight was determined by weighting 15 plants in the harvest part and fruit diameter and height were calculated by gauging the weighted fruit with a ruler and by taking the average of these values. The dry matter ratio was obtained after they were dried at $65^{\circ} \mathrm{C}$ in a drying oven for $48 \mathrm{~h}$ and fruit dry matter ratio was calculated. The detail of the experimental plot is shown in Figure 5.

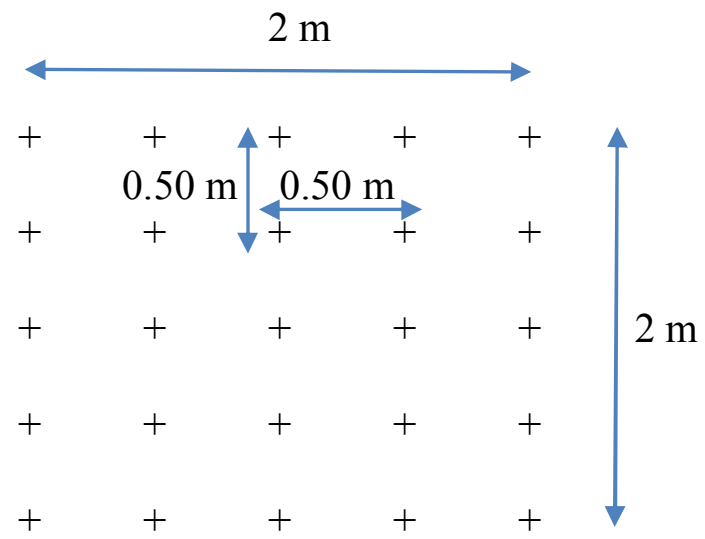

Figure 5. The detail of a plot

In different growth periods of tomato (vegetative, flowering, yield formation and ripening) fourteen deficit irrigation treatments were formed depending on full or deficit irrigation treatments. $75-50-25 \%$ of the deficit irrigations were applied in different growth stages of the plant, while $100 \%$ of irrigation water was used in full irrigation treatment. In line with this planning, irrigation treatments were planned like this: $\mathrm{V}_{100} \mathrm{~F}_{100} \mathrm{Y}_{100} \mathrm{R}_{100}, \mathrm{~V}_{75} \mathrm{FYR}, \mathrm{V}_{50} \mathrm{FYR}, \mathrm{V}_{25} \mathrm{FYR}, \mathrm{VF}_{75} \mathrm{YR}, \mathrm{VF}_{50} \mathrm{YR}, \mathrm{VF}_{25} \mathrm{YR}, \mathrm{VFY}_{75} \mathrm{R}$, $\mathrm{VFY}_{50} \mathrm{R}, \mathrm{VFY}_{25} \mathrm{R}, \mathrm{VFYR}_{75}, \mathrm{VFYR}_{50}, \mathrm{VFYR}_{25}, \mathrm{~V}_{0} \mathrm{~F}_{0} \mathrm{Y}_{0} \mathrm{R}_{0}$ (Table 2.).

Table 2. The experimental treatments

\begin{tabular}{|c|c|c|c|c|}
\hline \multirow{2}{*}{$\begin{array}{c}\text { Irrigation } \\
\text { treatments }\end{array}$} & \multicolumn{4}{|c|}{ Growth Stages } \\
\hline & Vegetative & Flowering & Yield Formation & Ripening \\
\hline V100F100Y100R100 & + & + & + & + \\
\hline V75FYR & $+\% 25$ deficit irrigation & + & + & + \\
\hline V50FYR & $+\% 50$ deficit irrigation & + & + & + \\
\hline V25FYR & $+\% 75$ deficit irrigation & + & + & + \\
\hline VF75YR & + & $+\% 25$ deficit irrigation & + & + \\
\hline VF50YR & + & $+\% 50$ deficit irrigation & + & + \\
\hline VF25YR & + & $+\% 75$ deficit irrigation & + & + \\
\hline VFY75R & + & + & $+\% 25$ deficit irrigation & + \\
\hline VFY 50R & + & + & $+\% 50$ deficit irrigation & + \\
\hline VFY25R & + & + & $+\% 75$ deficit irrigation & + \\
\hline VFYR75 & + & + & + & $+\% 25$ deficit irrigation \\
\hline VFYR50 & + & + & + & $+\% 50$ deficit irrigation \\
\hline VFYR25 & + & + & + & $+\% 75$ deficit irrigation \\
\hline VoFoYoRo & - & - & - & - \\
\hline
\end{tabular}

+: Water application in the specified period, -: without irrigation 
The irrigation equipment in greenhouse used in the study was given in Figure 6.

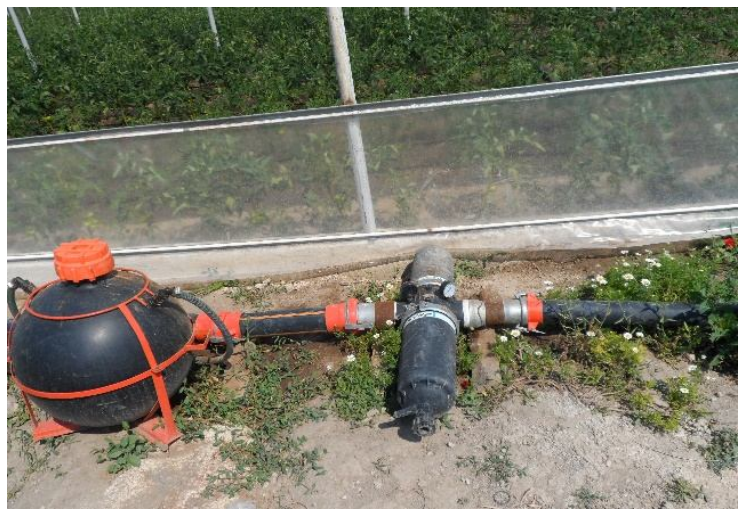

a

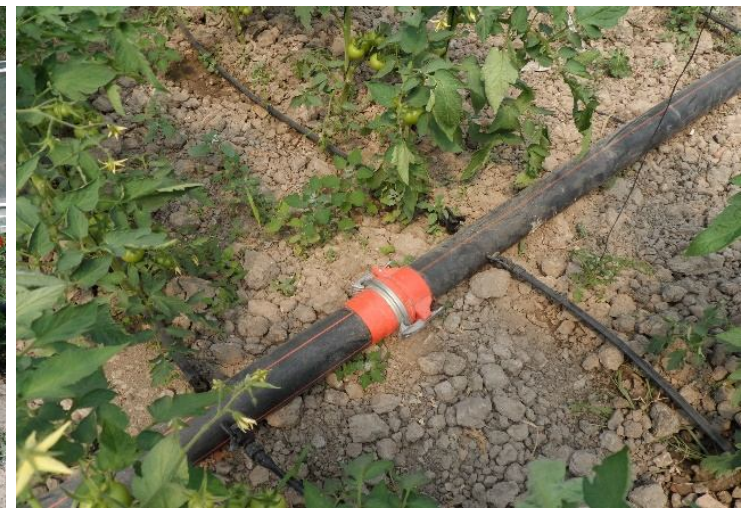

b

Figure 6. a Drip irrigation system. $\boldsymbol{b}$ Main and lateral pipes

In the trial, the plants were irrigated by drip irrigation method and water was used an irrigation well. Some features of the irrigation water were given in Table 3. The irrigation water has low-sodium risk and medium EC and its class is $\mathrm{C}_{2} \mathrm{~S}_{1}$ class. C2S1 irrigation water quality class has low sodium and medium electrical conductivity (salinity). Water in the C2S1 quality class can be used for be irrigated medium and highly resistant plants to salinity. In addition, C1S1 quality class water can be used in all plants and soil without creating harmful alkalinity. A study has been conducted on irrigating tomato by using C2S1 quality class water (Ashraf and Ewees, 2008).

Table 3. Specific properties of irrigation water

\begin{tabular}{c|c|c|c|c|c|c|c|c}
\hline \multirow{2}{*}{$\begin{array}{c}\text { Water } \\
\text { source }\end{array}$} & \multirow{2}{*}{$\left.\mathbf{E C}_{25 \mathbf{X}} \mathbf{( 1 0}^{\mathbf{6}}\right)$} & $\mathbf{N a}^{+}$ & $\mathbf{K}^{+}$ & $\mathbf{C a}^{\mathbf{2 +}}$ & $\mathbf{M g}^{\mathbf{2}}$ & \multirow{2}{*}{$\mathbf{P H}$} & \multirow{2}{*}{ Class } & \multirow{2}{*}{ SAR } \\
\cline { 3 - 5 } & & \multicolumn{5}{|c|}{$\left.\mathbf{L}^{-1}\right)$} & & \\
\hline Deep well & 715 & 2.3 & 2.56 & 9.25 & 5.7 & 7.12 & $\mathrm{C}_{2} \mathrm{~S}_{1}$ & 0.85 \\
\hline
\end{tabular}

In four growth stages the soil moisture contains of the soil was followed before and after irrigation with a gravimetric method in every $30 \mathrm{~cm}$ up to $120 \mathrm{~cm}$ depth.

The water balance equation was used to calculate evapotranspiration (ET) (Eq. 1).

$$
\mathrm{ET}=\mathrm{I}+\mathrm{P}-\mathrm{R}_{\mathrm{f}}-\mathrm{D}_{\mathrm{p}} \pm \Delta \mathrm{S}
$$

where ET represents the evapotranspiration, I shows the irrigation water amount during the period $(\mathrm{mm}), P$ is the total precipitation, $R_{f}$ is the amount of the surface flow $(\mathrm{mm})$, $\mathrm{D}_{\mathrm{p}}$ indicates the deep drainage $(\mathrm{mm})$ and $\Delta \mathrm{S}$ is the soil water content at the beginning and end of the period $(\mathrm{mm} / 120 \mathrm{~cm})$. Before planting seedlings, water was given to the crop by the drip irrigation method. Total precipitation $(P)$ and surface flow $\left(R_{f}\right)$ were omitted due to the plant production in the greenhouse. The soil water in the deeper than $120 \mathrm{~cm}$ was taken as the deep drainage $\left(\mathrm{D}_{\mathrm{p}}\right)$ and the deep drainage $(\mathrm{Dp})$ was neglected.

The intervals of lateral were equal to the plant row intervals in the trial. Therefore the percentage of wetted area was calculated by the equation as follows (Eq. 2). 


$$
P=\frac{S d}{S l} 100
$$

where $\mathrm{P}$ is the percentage of wetted area, Sd and S1 are the interval of dripper and the intervals of lateral, respectively. The amount of irrigation water to be applied in each irrigation ( $E q .3)$ was found by the equation given below.

$$
\mathrm{dn}=\frac{(F C-W P) R y}{100} \text { yt D } \frac{P}{100}
$$

where $\mathrm{dn}$ is the amount of irrigation water to be applied in each irrigation, FC and WP are the field capacity and wilting point, respectively. $\mathrm{yt}$ is the soil bulk density, D is wetted soil depth, $\mathrm{P}$ is the percentage of wetted area.

In this trial, the relationships between yield and ET was described by Steward Model (Eq. 4) (Stewart et al., 1975; Doorenbos and Kassam, 1979). The equation can be given as:

$$
\left(1-\frac{Y a}{Y m}\right)=k y\left(1-\frac{E T a}{E T m}\right)
$$

where $Y_{m}(t / h a)$ and $Y_{a}(t / h a)$ are maximal and actual yield, respectively, $\operatorname{ET}_{m}(\mathrm{~mm})$ and $\mathrm{ET}_{\mathrm{a}}(\mathrm{mm})$ are maximal and actual evapotranspiration, respectively. The yield response factor is shown as $\mathrm{k}_{\mathrm{y}}$. WUE values were determined to assess irrigation efficiency in treatments. WUE and IWUE terms refer to contribution of irrigation water to effective use of plant production stages (Bos, 1980). WUE was calculated by dividing the fruit yield by seasonal evapotranspiration (ET). IWUE was predicted as (Zhang et al., 1999):

$$
\mathrm{IWUE}=\frac{\left(Y_{1}-Y_{N I}\right)}{I}
$$

where $Y_{1}$ is fruit yield of irrigated treatments $\left(t\right.$ ha $\left.{ }^{-1}\right)$ and $Y_{N I}$ is the fruit yield of non-irrigated treatment $\left(\mathrm{t} \mathrm{ha}^{-1}\right)$ and $\mathrm{I}$ is the amount of irrigation water $(\mathrm{mm})$. The water content of the soil up to $120 \mathrm{~cm}$ depth was calculated before the seedlings were planted into the soil. Before starting irrigations, moisture level of the soil was completed to the level of field capacity in all treatments. Irrigation was begun on May 02 in 2009 and May 05 in 2010 and it was repeated every 7 days. The irrigation water amounts for the four growth stages were given in Table 4. Crop evapotranspiration for growth periods of tomato are given in Table 5.

Yield and quality parameters were evaluated. Variance analysis of yield and quality parameters were evaluated according to LSD multiple comparison test $(p<0.05)$. Variance analysis was done with the values of yield productivity and quality parameters by using MSTAT-C and MINITAB software (Steel and Torrie, 1980).

\section{Results}

In 2009 and 2010 years, the highest irrigation water was found in $V_{100} F_{100} Y_{100} R_{100}$ treatment as 554-556 $\mathrm{mm}$ and minimal irrigation water was found in $\mathrm{V}_{0} \mathrm{~F}_{0} \mathrm{Y}_{0} \mathrm{R}_{0}$ 
treatment as $0-0 \mathrm{~mm}$ respectively. Crop water use of tomato $\left(\mathrm{ET}_{\mathrm{c}}\right)$ increased with the increment in the water amount. ET was found as 300-735 mm in 2009 and as 340-746 $\mathrm{mm}$ in 2010 in $\mathrm{V}_{100} \mathrm{~F}_{100} \mathrm{Y}_{100} \mathrm{R}_{100}$ and $\mathrm{V}_{0} \mathrm{~F}_{0} \mathrm{Y}_{0} \mathrm{R}_{0}$ treatments, respectively. The irrigation water and yields are presented in Table 6.

Crop water production functions (ky and $\mathrm{R}^{2}$ values) obtained for each growth stage (vegetative, flowering, yield formation, ripening) and total growing season in 2009 and 2010 were given in Table 7.

Linear relationships between $\mathrm{ET}_{\mathrm{c}}$ with $\mathrm{Y}_{\mathrm{a}}$, and IW with $\mathrm{Y}_{\mathrm{a}}$ were observed for 2009 year. The relationship equation is as follows; $Y_{a}=0.2185 E T_{c}-58.437$ with $R^{2}=0.9402$ and $Y_{a}=0.1576 I W+2.2813$ with $R^{2}=0.99$ (Figs. 2 and 3). Linear relationships between $\mathrm{ET}_{\mathrm{c}}$ with $\left(\mathrm{Y}_{\mathrm{a}}\right)$, and IW with $\mathrm{Y}_{\mathrm{a}}$ were observed for 2010 year. The relationship equation is as follows: $Y_{a}=0.228 E T_{c}-67.477$ with $R^{2}=0.9115$ and $Y_{a}=0.1569 I W+3.4724$ with $R^{2}=0.99$ (Fig. 7).

When the results were taken into consideration, yield was substantially affected by irrigation applications (Figs. 2 and 3) the maximum values of yield were found as $92.2 \mathrm{t}$ $\mathrm{ha}^{-1}$ and $93.4 \mathrm{t} \mathrm{ha}^{-1}$ in $\mathrm{V}_{100} \mathrm{~F}_{100} \mathrm{Y}_{100} \mathrm{R}_{100}$ treatment for 2009 and 2010 years, respectively (Tables 8 and 9).

Table 4. The irrigation water applied for the four growth stages

\begin{tabular}{|c|c|c|c|c|c|c|c|c|c|c|}
\hline \multicolumn{11}{|c|}{ Irrigation Water (mm) } \\
\hline \multirow{2}{*}{ Treatments } & \multicolumn{2}{|c|}{ Vegetative } & \multicolumn{2}{|c|}{ Flowering } & \multicolumn{2}{|c|}{ Yield Formation } & \multicolumn{2}{|c|}{ Ripening } & \multicolumn{2}{|c|}{ Total } \\
\hline & 2009 & 2010 & 2009 & 2010 & 2009 & 2010 & 2009 & 2010 & 2009 & 2010 \\
\hline V100F100Y100R100 & 60 & 50 & 240 & 230 & 200 & 198 & 54 & 78 & 554,0 & 556,0 \\
\hline V75FYR & 45 & 38 & 240 & 230 & 200 & 198 & 54 & 78 & 532,0 & 544,0 \\
\hline V50FYR & 30 & 25 & 240 & 230 & 200 & 198 & 54 & 78 & 524,0 & 531,0 \\
\hline V25FYR & 15 & 12 & 240 & 230 & 200 & 198 & 54 & 78 & 509,0 & 518,0 \\
\hline VF75YR & 80 & 70 & 180 & 172,5 & 200 & 198 & 54 & 78 & 550,0 & 518,0 \\
\hline VF50YR & 80 & 70 & 120 & 115 & 200 & 198 & 54 & 78 & 535,0 & 481,0 \\
\hline VF25YR & 80 & 70 & 60 & 57,5 & 200 & 198 & 54 & 78 & 534,0 & 454,0 \\
\hline VFY75R & 80 & 70 & 240 & 230 & 150 & 148,5 & 54 & 78 & 524,0 & 526,0 \\
\hline VFY50R & 80 & 70 & 240 & 230 & 100 & 99 & 54 & 78 & 514,0 & 507,0 \\
\hline VFY25R & 80 & 70 & 240 & 230 & 50 & 49,5 & 54 & 78 & 504,0 & 495,0 \\
\hline VFYR75 & 80 & 70 & 240 & 230 & 200 & 198 & 40,5 & 58,5 & 525,0 & 556,0 \\
\hline VFYR50 & 80 & 70 & 240 & 230 & 200 & 198 & 27 & 39 & 517,0 & 537,0 \\
\hline VFYR25 & 80 & 70 & 240 & 230 & 200 & 198 & 13,5 & 19,5 & 514,0 & 518,0 \\
\hline V0F0Y0R0 & 0 & 0 & 0 & 0 & 0 & 0 & 0 & 0 & 0,0 & 0,0 \\
\hline
\end{tabular}

Table 5. Crop evapotranspiration for growth periods of tomato

\begin{tabular}{|c|c|c|c|c|c|c|c|c|c|c|}
\hline \multicolumn{10}{|c|}{ Crop Evapotranspiration (mm) } \\
\hline \multirow{2}{*}{ Treatments } & \multicolumn{1}{|c|}{ Vegetative } & \multicolumn{2}{c|}{ Flowering } & \multicolumn{2}{c|}{ Yield Formation } & \multicolumn{3}{|c|}{ Ripening } & \multicolumn{2}{c|}{ Total } \\
\cline { 2 - 13 } & 2009 & 2010 & 2009 & 2010 & 2009 & 2010 & 2009 & 2010 & 2009 & 2010 \\
\hline V100F100Y100R100 & 140 & 145 & 240 & 240 & 210 & 226 & 135 & 135 & 725 & 746 \\
\hline V75FYR & 130 & 132 & 226 & 225 & 192 & 220 & 117 & 107 & 665 & 684 \\
\hline V50FYR & 126 & 132 & 214 & 225 & 184 & 196 & 116 & 107 & 640 & 660 \\
\hline V25FYR & 126 & 130 & 212 & 222 & 178 & 190 & 116 & 104 & 632 & 646 \\
\hline VF75YR & 137 & 138 & 224 & 230 & 206 & 202 & 123 & 118 & 690 & 688 \\
\hline VF50YR & 138 & 138 & 230 & 228 & 208 & 183 & 104 & 112 & 680 & 661 \\
\hline VF25YR & 136 & 135 & 227 & 225 & 206 & 174 & 101 & 110 & 670 & 644 \\
\hline VFY75R & 129 & 137 & 206 & 232 & 200 & 206 & 120 & 117 & 655 & 692 \\
\hline VFY50R & 129 & 132 & 215 & 226 & 190 & 188 & 112 & 92 & 646 & 638 \\
\hline VFY25R & 130 & 125 & 216 & 210 & 185 & 164 & 103 & 105 & 634 & 604 \\
\hline VFYR75 & 131 & 137 & 220 & 211 & 180 & 220 & 109 & 113 & 640 & 681 \\
\hline VFYR50 & 122 & 138 & 219 & 214 & 190 & 202 & 104 & 116 & 635 & 670 \\
\hline VFYR25 & 134 & 140 & 222 & 220 & 142 & 172 & 112 & 109 & 610 & 641 \\
\hline V0F0Y0R0 & 70 & 80 & 90 & 100 & 80 & 90 & 60 & 70 & 300 & 340 \\
\hline
\end{tabular}


Table 6. Relationship between yield and yield response factor (ky) with the decrease in water use, for tomato in 2009 and 2010 years

\begin{tabular}{|c|c|c|c|c|c|c|c|c|c|}
\hline $\begin{array}{l}\text { Irrigation } \\
\text { Treatment }\end{array}$ & Yield $\left(\mathrm{t} \mathrm{ha}^{-1}\right)$ & $\begin{array}{c}\text { Applied } \\
\text { Water (mm) }\end{array}$ & $\mathrm{ETa}(\mathrm{mm})$ & $\mathrm{ETa} / \mathrm{ETm}$ & $\mathrm{Ya} / \mathrm{Ym}$ & 1-(ETa/Etm) & 1-(Ya/Ym) & ky & ky \\
\hline $\mathrm{V}_{100} \mathrm{~F}_{100} \mathrm{Y}_{100 \mathrm{R}} 100$ & 92,2 & 554,0 & 725 & 1,000 & 1,000 & 0,000 & 0,000 & 0,000 & 0,000 \\
\hline V75FYR & 88,6 & 532,0 & 665 & 0,917 & 0,961 & 0,083 & 0,039 & 0,472 & \multirow{3}{*}{0,595} \\
\hline $\mathrm{V}_{50} \mathrm{FYR}$ & 86,4 & 524,0 & 640 & 0,883 & 0,937 & 0,117 & 0,063 & 0,537 & \\
\hline $\mathrm{V}_{25} \mathrm{FYR}$ & 83,0 & 509,0 & 632 & 0,872 & 0,900 & 0,128 & 0,100 & 0,778 & \\
\hline VF75YR & 83,8 & 550,0 & 690 & 0,952 & 0,909 & 0,048 & 0,091 & 1,887 & \multirow{3}{*}{1,592} \\
\hline VF50YR & 83,6 & 535,0 & 680 & 0,938 & 0,907 & 0,062 & 0,093 & 1,503 & \\
\hline$V F_{25} Y R$ & 82,5 & 534,0 & 670 & 0,924 & 0,895 & 0,076 & 0,105 & 1,387 & \\
\hline VFY75R & 85,8 & 524,0 & 655 & 0,903 & 0,931 & 0,097 & 0,069 & 0,719 & \multirow{3}{*}{0,76} \\
\hline $\mathrm{VFY}_{50 \mathrm{R}}$ & 84,6 & 514,0 & 646 & 0,891 & 0,918 & 0,109 & 0,082 & 0,756 & \\
\hline $\mathrm{VFY}_{25} \mathrm{R}$ & 82,8 & 504,0 & 634 & 0,874 & 0,898 & 0,126 & 0,102 & 0,812 & \\
\hline VFYR75 & 86,7 & 525,0 & 640 & 0,883 & 0,940 & 0,117 & 0,060 & 0,509 & \multirow{3}{*}{0,613} \\
\hline VFYR50 & 84,4 & 517,0 & 635 & 0,876 & 0,915 & 0,124 & 0,085 & 0,681 & \\
\hline VFYR25 & 82,7 & 514,0 & 610 & 0,841 & 0,897 & 0,159 & 0,103 & 0,650 & \\
\hline \multirow[t]{2}{*}{$\mathrm{V}_{0} \mathrm{~F}_{0} \mathrm{Y}_{0} \mathrm{RO}_{0}$} & 2,00 & 0,0 & 300 & 0,414 & 0,022 & 0,586 & 0,978 & 1,669 & 1,669 \\
\hline & & & & & & & & & 1,05 \\
\hline $\begin{array}{l}\text { Irrigation } \\
\text { Treatment }\end{array}$ & Yield $\left(\mathrm{t} \mathrm{ha}^{-1}\right)$ & $\begin{array}{c}\text { Applied } \\
\text { Water (mm) }\end{array}$ & $\mathrm{ETa}(\mathrm{mm})$ & $\mathrm{ETa} / \mathrm{ETm}$ & $\mathrm{Ya} / \mathrm{Ym}$ & 1-(ETa/Etm) & 1-(Ya/Ym) & ky & ky \\
\hline $\mathrm{V}_{100} \mathrm{~F}_{100} \mathrm{Y}_{100} \mathrm{R}_{100}$ & 93,4 & 556 & 746 & 1,000 & 1,000 & 0,000 & 0,000 & 0,000 & 0,000 \\
\hline V75FYR & 90,1 & 544 & 684 & 0,917 & 0,965 & 0,083 & 0,035 & 0,425 & \multirow[b]{3}{*}{0,528} \\
\hline $\mathrm{V}_{50} \mathrm{FYR}$ & 87,9 & 531 & 660 & 0,885 & 0,941 & 0,115 & 0,059 & 0,511 & \\
\hline $\mathrm{V}_{25} \mathrm{FYR}$ & 85,3 & 518 & 646 & 0,866 & 0,913 & 0,134 & 0,087 & 0,647 & \\
\hline VF75YR & 80,5 & 518 & 688 & 0,922 & 0,862 & 0,078 & 0,138 & 1,776 & \multirow[b]{3}{*}{1,583} \\
\hline VF50YR & 78,6 & 481 & 661 & 0,886 & 0,842 & 0,114 & 0,158 & 1,391 & \\
\hline$V F_{25} Y R$ & 73,2 & 454 & 644 & 0,863 & 0,784 & 0,137 & 0,216 & 1,582 & \\
\hline VFY75R & 83,8 & 526 & 692 & 0,928 & 0,897 & 0,072 & 0,103 & 1,420 & \multirow[b]{3}{*}{0,969} \\
\hline $\mathrm{VFY}_{50 \mathrm{R}}$ & 82,8 & 507 & 638 & 0,855 & 0,887 & 0,145 & 0,113 & 0,784 & \\
\hline $\mathrm{VFY}_{25} \mathrm{R}$ & 80,9 & 495 & 604 & 0,810 & 0,866 & 0,190 & 0,134 & 0,703 & \\
\hline VFYR75 & 90,6 & 556 & 681 & 0,913 & 0,970 & 0,087 & 0,030 & 0,344 & \multirow[b]{3}{*}{0,479} \\
\hline VFYR50 & 89,2 & 537 & 670 & 0,913 & 0,955 & 0,087 & 0,045 & 0,516 & \\
\hline VFYR25 & 85,8 & 518 & 641 & 0,859 & 0,919 & 0,141 & 0,081 & 0,578 & \\
\hline \multirow[t]{2}{*}{$V_{0} F_{0} Y_{0} R_{0}$} & 4,0 & 0 & 340 & 0,456 & 0,043 & 0,544 & 0,957 & 1,759 & 1,759 \\
\hline & & & & & & & & & 1,06 \\
\hline
\end{tabular}

Table 7. Crop water production functions obtained for each growth stage and total growing season in 2009 and 2010 years

\begin{tabular}{|c|c|c|}
\hline Year & Period & Production Functions \\
\hline & $\mathrm{V}$ & $\mathrm{ky}=0.60, \mathrm{R}^{2}=0.8395$ \\
\hline & $\mathrm{F}$ & $\mathrm{ky}=1.59, \mathrm{R}^{2}=0.8622$ \\
\hline 2009 & $\mathrm{Y}$ & $\mathrm{ky}=0.76, \mathrm{R}^{2}=0.9989$ \\
\hline & $\mathrm{R}$ & $\mathrm{ky}=0.61, \mathrm{R}^{2}=0.8078$ \\
\hline & Seasonal & $\mathrm{ky}=1.05, \mathrm{R}^{2}=0.9402$ \\
\hline & $\mathrm{V}$ & $\mathrm{ky}=0.52, \mathrm{R} 2=0.9610$ \\
\hline \multirow{2}{*}{2010} & $\mathrm{~F}$ & $\mathrm{ky}=1.58, \mathrm{R} 2=0.8480$ \\
\hline & $\mathrm{Y}$ & $\mathrm{ky}=0.97, \mathrm{R} 2=0.9082$ \\
\hline & $\mathrm{R}$ & $\mathrm{k} y=0.48, \mathrm{R} 2=0.9997$ \\
\hline & Seasonal & $\mathrm{ky}=1.06, \mathrm{R} 2=0.9115$ \\
\hline
\end{tabular}




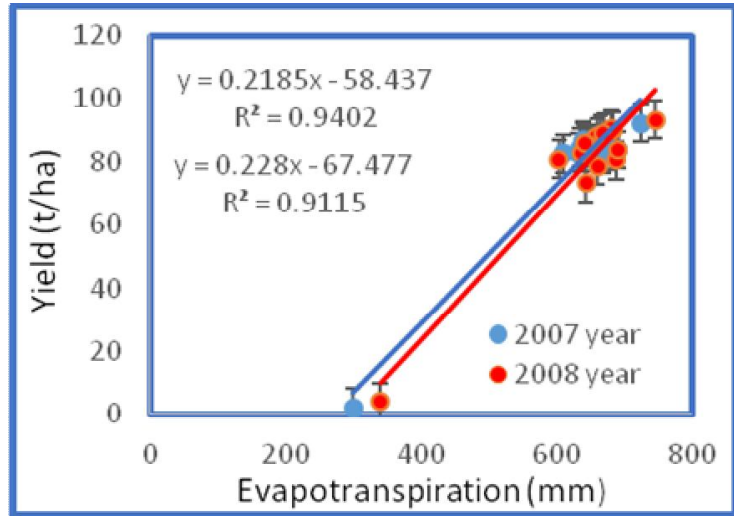

a

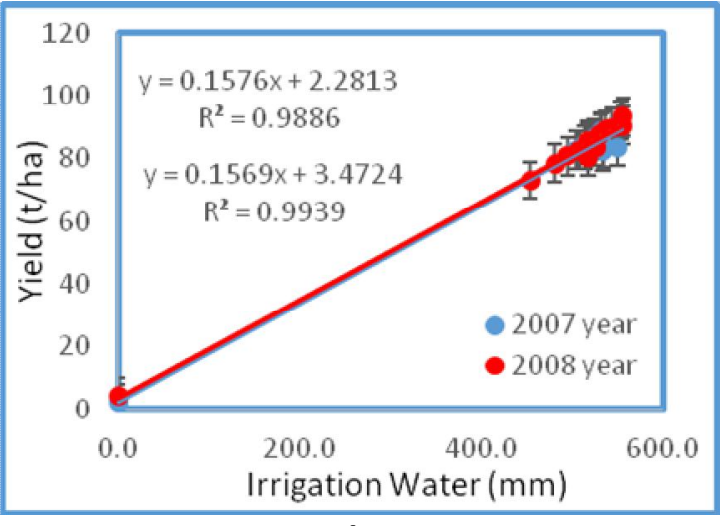

b

Figure 7. $\boldsymbol{a}$ The relationship between crop water consumption and yield. $\boldsymbol{b}$ The relationship between irrigation water and yield

Table 8. Effects of irrigation treatments on yield and quality parameters of tomato in 2009 year

\begin{tabular}{c|c|c|c|c|c}
\hline Irrigation treatment & Yield (t ha $^{-1} \mathbf{)}$ & $\begin{array}{c}\text { Fruit } \\
\text { weight }(\mathbf{g})\end{array}$ & $\begin{array}{c}\text { Fruit } \\
\text { diameter } \mathbf{( c m})\end{array}$ & $\begin{array}{c}\text { Fruit height } \\
\mathbf{( c m )}\end{array}$ & $\begin{array}{c}\text { Dry matter ratio } \\
\mathbf{( \% )}\end{array}$ \\
\hline V100F100Y100R100 & $92.2 \mathrm{a}$ & $220.0 \mathrm{a}$ & $8.2 \mathrm{a}$ & $7.5 \mathrm{a}$ & $6.0 \mathrm{~h}$ \\
V75FYR & $88.6 \mathrm{~b}$ & $217.0 \mathrm{ab}$ & $8.0 \mathrm{ab}$ & $7.4 \mathrm{ab}$ & $7.4 \mathrm{~g}$ \\
V50FYR & $86.4 \mathrm{c}$ & $214.0 \mathrm{bc}$ & $7.7 \mathrm{bc}$ & $7.2 \mathrm{abc}$ & $7.6 \mathrm{fg}$ \\
V25FYR & $83.0 \mathrm{fg}$ & $213.0 \mathrm{bc}$ & $7.5 \mathrm{~cd}$ & $7.1 \mathrm{abcd}$ & $7.9 \mathrm{adefg}$ \\
VF75YR & $83.8 \mathrm{efg}$ & $190.0 \mathrm{~h} 1$ & $6.8 \mathrm{ef}$ & $6.8 \mathrm{cdef}$ & $7.7 \mathrm{efg}$ \\
VF50YR & $83.6 \mathrm{efg}$ & $187.0 \mathrm{jj}$ & $6.5 \mathrm{fg}$ & $6.6 \mathrm{efg}$ & $7.9 \mathrm{defg}$ \\
VF25YR & $82.5 \mathrm{~g}$ & $182.0 \mathrm{j}$ & $6.2 \mathrm{~g}$ & $6.3 \mathrm{~g}$ & $7.9 \mathrm{defg}$ \\
VFY75R & $85.8 \mathrm{~cd}$ & $198.0 \mathrm{fg}$ & $7.3 \mathrm{~cd}$ & $7.0 \mathrm{bcde}$ & $8.0 \mathrm{def}$ \\
VFY50R & $84.6 \mathrm{de}$ & $195.0 \mathrm{gh}$ & $7.1 \mathrm{de}$ & $6.7 \mathrm{defg}$ & $8.2 \mathrm{cde}$ \\
VFY25R & $82.8 \mathrm{~g}$ & $191.0 \mathrm{~h} 1$ & $7.1 \mathrm{de}$ & $6.5 \mathrm{fg}$ & $8.3 \mathrm{~cd}$ \\
VFYR75 & $86.7 \mathrm{c}$ & $210.0 \mathrm{~cd}$ & $7.4 \mathrm{~cd}$ & $7.3 \mathrm{ab}$ & $8.4 \mathrm{bcd}$ \\
VFYR50 & $84.4 \mathrm{def}$ & $206.0 \mathrm{de}$ & $7.3 \mathrm{~cd}$ & $7.1 \mathrm{abcd}$ & $8.6 \mathrm{bc}$ \\
VFYR25 & $82.7 \mathrm{~g}$ & $202.0 \mathrm{ef}$ & $7.2 \mathrm{de}$ & $6.8 \mathrm{cdef}$ & $8.9 \mathrm{~b}$ \\
V0F0Y0R0 & $2.0 \mathrm{~h}$ & $62.0 \mathrm{k}$ & $2.0 \mathrm{~h}$ & $2.7 \mathrm{~h}$ & $13,5 \mathrm{a}$ \\
Treatments & $*$ & $*$ & $*$ & $*$ & $*$ \\
Blocks & is & is & is & is & is \\
\hline
\end{tabular}

**Correlation is significant at the 0.05 level. ns: non-significant correlation

When $\mathrm{V}_{100} \mathrm{~F}_{100} \mathrm{Y}_{100} \mathrm{R}_{100}$ treatment was made comparison with the other irrigation treatments, yield losses were determined as $4.1 \%, 6.7 \%, 11.1 \%, 10.0 \%, 10.3 \%, 11.8 \%$, $7.5 \%, 9.0 \%, 11.4 \%, 6.3 \%, 9.2 \%, 11.5 \%$, and $4510.0 \%$ in 2009 and $3.7 \%, 6.3 \%, 9.5 \%$, $16.0 \%, 18.8 \%, 27.6 \%, 11.5 \%, 12.8 \%, 15.5 \%, 3.1 \%, 4.7 \%, 8.9 \%$ and $2235.0 \%$ in 2010 . In the trial, it was observed that at $\mathrm{P}<0.05$ level has a significant effect on the yield and quality parameters of deficit irrigation. 
Table 9. Effects of irrigation treatments on yield and quality parameters of tomato in 2010 year

\begin{tabular}{c|c|c|c|c|c}
\hline Irrigation treatment & Yield (t ha $\left.\mathbf{- 1}^{-1}\right)$ & $\begin{array}{c}\text { Fruit weight } \\
\mathbf{( k g})\end{array}$ & $\begin{array}{c}\text { Fruit diameter } \\
\mathbf{( c m )}\end{array}$ & $\begin{array}{c}\text { Fruit height } \\
\mathbf{( c m})\end{array}$ & $\begin{array}{c}\text { Dry matter } \\
\text { ratio (\%) }\end{array}$ \\
\hline V100F100Y100R100 & $93.4 \mathrm{a}$ & $220 \mathrm{a}$ & $8.6 \mathrm{a}$ & $7.5 \mathrm{a}$ & $6.5 \mathrm{e}$ \\
V75FYR & $90.1 \mathrm{bc}$ & $210 \mathrm{ab}$ & $8.2 \mathrm{a}$ & $7.2 \mathrm{ab}$ & $8.0 \mathrm{~d}$ \\
V50FYR & $89.9 \mathrm{~d}$ & $207 \mathrm{~b}$ & $7.9 \mathrm{ab}$ & $6.9 \mathrm{ab}$ & $8.3 \mathrm{~cd}$ \\
V25FYR & $89.7 \mathrm{e}$ & $203 \mathrm{~b}$ & $7.7 \mathrm{bc}$ & $6.7 \mathrm{bc}$ & $8.6 \mathrm{bc}$ \\
VF75YR & $82.5 \mathrm{~g}$ & $115 \mathrm{f}$ & $5.0 \mathrm{efg}$ & $5.2 \mathrm{~cd}$ & $8.4 \mathrm{bcd}$ \\
VF50YR & $79.6 \mathrm{~h}$ & $109 \mathrm{fg}$ & $4.7 \mathrm{gh}$ & $4.8 \mathrm{de}$ & $8.7 \mathrm{bc}$ \\
VF25YR & $74.5 \mathrm{i}$ & $102 \mathrm{~g}$ & $4.5 \mathrm{~h}$ & $4.5 \mathrm{e}$ & $8.9 \mathrm{~b}$ \\
VFY75R & $85.4 \mathrm{f}$ & $131 \mathrm{~cd}$ & $5.8 \mathrm{def}$ & $5.8 \mathrm{bc}$ & $8.4 \mathrm{bcd}$ \\
VFY50R & $83.0 \mathrm{f}$ & $125 \mathrm{de}$ & $5.4 \mathrm{fgh}$ & $5.5 \mathrm{cde}$ & $8.6 \mathrm{bc}$ \\
VFY25R & $82.8 \mathrm{~g}$ & $117 \mathrm{e}$ & $5.1 \mathrm{gh}$ & $5.1 \mathrm{de}$ & $8.9 \mathrm{~b}$ \\
VFYR75 & $90.6 \mathrm{~b}$ & $210 \mathrm{c}$ & $8.3 \mathrm{~cd}$ & $7.3 \mathrm{~cd}$ & $8.3 \mathrm{~cd}$ \\
VFYR50 & $90.2 \mathrm{~cd}$ & $207 \mathrm{~cd}$ & $8.0 \mathrm{cde}$ & $7.0 \mathrm{bc}$ & $8.7 \mathrm{bc}$ \\
VFYR25 & $89.8 \mathrm{e}$ & $203 \mathrm{de}$ & $7.7 \mathrm{efg}$ & $6.8 \mathrm{ab}$ & $8.9 \mathrm{~b}$ \\
V0F0Y0R0 & $4.0 \mathrm{j}$ & $58 \mathrm{~h}$ & 3.51 & $3.7 \mathrm{f}$ & $13.7 \mathrm{a}$ \\
Treatments & $*$ & $*$ & $*$ & $*$ & $*$ \\
Blocks & is & is & is & is & is \\
\hline
\end{tabular}

${ }^{* *}$ Correlation is significant at the 0.05 level. ns: non-significant correlation

While a positive straight line relationship was obtained between the water amount and the yield, fruit weight, diameter, height; a negative straight line relationship was obtained between the irrigation amount and dry matter ratio. As for that the relationship, these results were determined: fruit weight $(2009)=0.2637 \mathrm{~W}+63.179, \mathrm{R}^{2}=0.90$ and fruit weight $\quad(2010)=0.288 \mathrm{IW}+56.976, \quad \mathrm{R}^{2}=0.98 \quad$ (Fig. 8a); fruit diameter $(2009)=0.0099 \mathrm{IW}+2.0412, \mathrm{R}^{2}=0.87$ and fruit diameter $(2010)=0.0096+2.3538$, $\mathrm{R}^{2}=0.92$ (Fig. 8b); fruit height $(2009)=0.0081 \mathrm{IW}+2.7108, \mathrm{R}^{2}=0.91$ and fruit height $(2010)=0.0089 \mathrm{IW}+2.4269, \quad \mathrm{R}^{2}=0.98 \quad$ (Fig. 8c); dry matter ratio $(2009)=-$ $0.0109 \mathrm{IW}+13.619, \quad \mathrm{R}^{2}=0.88$ and dry matter ratio $(2010)=-0.0104+13.763$, $\mathrm{R}^{2}=0.90$ (Fig. 8d).

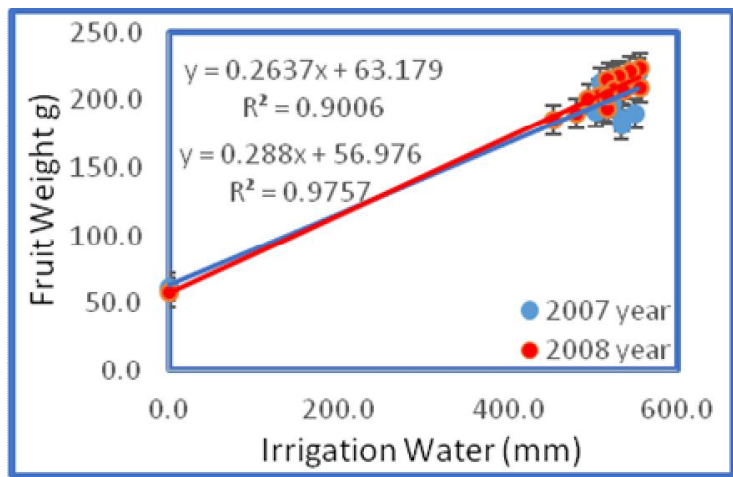

a

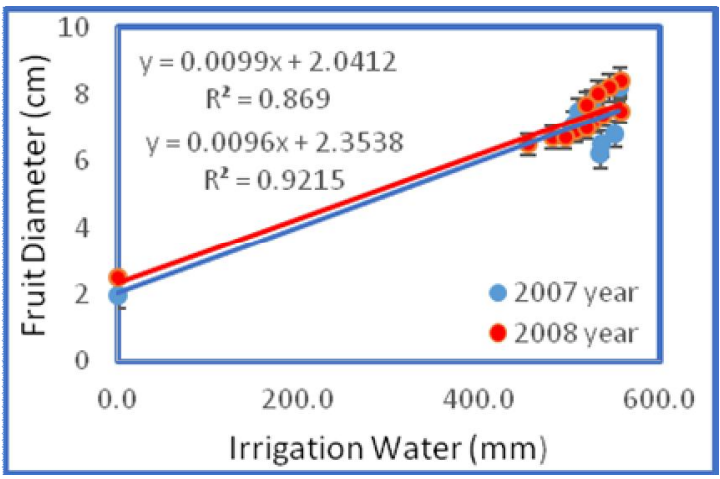

b 


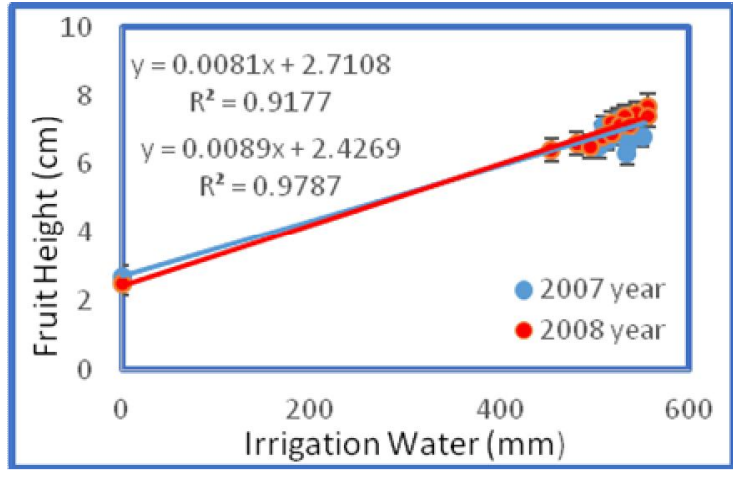

c

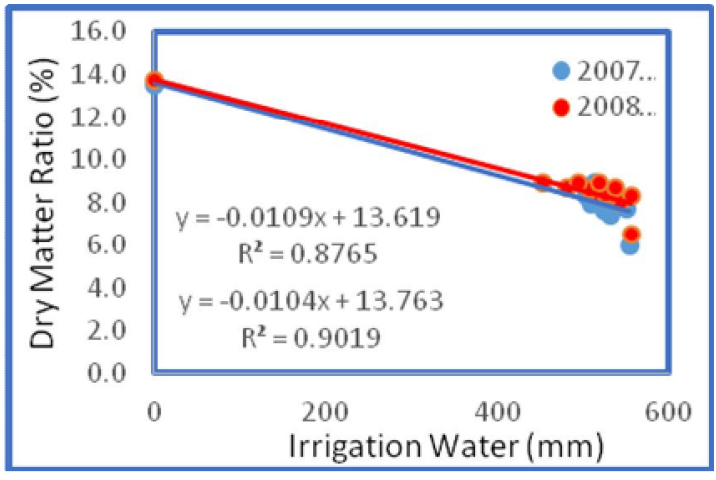

d

Figure 8. Relationship between irrigation water and fruit weight, diameter, height and dry matter ratio

\section{Crop yield response factor $\left(k_{y}\right)$}

The linear relationship between relative crop evapotranspiration and relative yield decrease is given the ky value. It is regarded as the yield response to the relative crop evapotranspiration. In another saying, it represents the declines in the yield as a result of each deficient level in water depletion. Seasonal ky values were determined as 1.05 (2009 year) and 1.06 (2010 year) (Fig. 9). Ky value increased with the increase in the water deficit. This result was relatively small with regard to seasonal crop yield response factors in four different crop growth stages of the tomatoes, while it was consistent with the crop yield response factors in each growth factors given in literature. The difference between these two results may refer to the differences between the empirical, climatic and seedling quality.

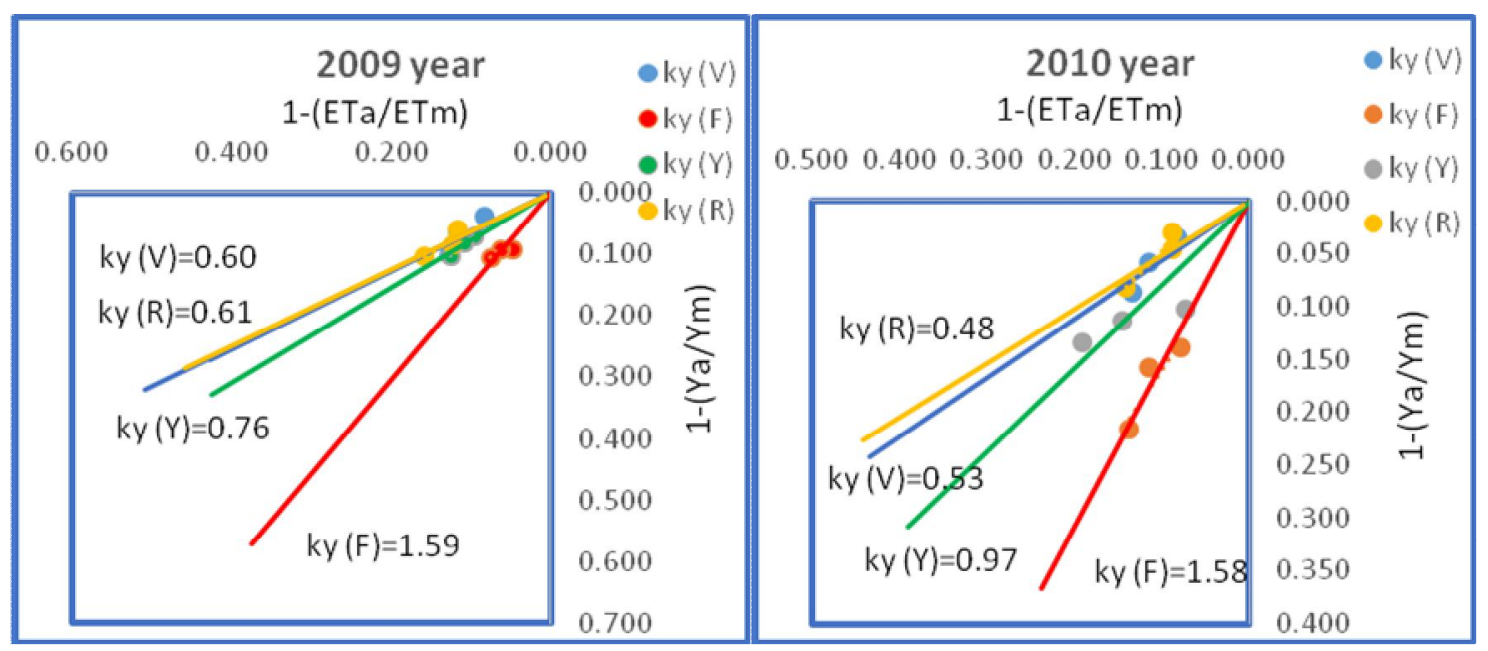

Figure 9. The relationship between relative yield decrease and relative evapotranspiration deficit for the experimental years

\section{Water use efficiencies}

WUE and IWUE values of the 2009 and 2010 years appeared differently in different treatments (Table 10). The maximum WUE values for 2009 year were found as 0.13 , 
$0.14,0.13-0.14,0.13,0.14 \mathrm{~kg} \mathrm{~mm}^{-1}$ and were found $0.13,0.13,013-0.13,0.13$, $0.13 \mathrm{~kg} \mathrm{~mm}{ }^{-1}$ from V75FYR, V50FYR, V25FYR and VFYR $75, V_{F Y R}$, VFYR 25 treatments for 2010 year, respectively. IWUE values for 2009 year were found as 0.17 , $0.16,0.16-0.17,0.16,0.16 \mathrm{~kg} . \mathrm{mm}^{-1}$ and were found $0.17,0.17,0.16-0.16,0.17$, $0.17 \mathrm{~kg} \mathrm{~mm}^{-1}$ from V75FYR, V50FYR, V25FYR and VFYR $75, V_{F Y R}, V_{F Y R} 5$ treatments for 2010 year, respectively. When WUE and IWUE values were taken into consideration, the maximum WUE and IWUE values were obtained in vegetative and ripening periods and the lowest value was obtained from flowering and yield formation periods. In other words, the maximum yields were obtained from vegetative and ripening periods and the most water saving was supplied with deficit irrigation only in the vegetative and ripening periods of the tomato.

Table 10. WUE and IWUE values for the tomato at fourteen irrigation treatments

\begin{tabular}{|c|c|c|c|c|c|c|c|}
\hline \multicolumn{4}{|c|}{2009 year } & \multicolumn{4}{|c|}{2010 year } \\
\hline $\begin{array}{l}\text { Irrigation } \\
\text { Treatment }\end{array}$ & Yield $\left(\mathrm{t} \mathrm{ha}^{-1}\right)$ & $\begin{array}{c}\text { WUE } \\
\left(\mathrm{kg} / \mathrm{m}^{3}\right)\end{array}$ & $\begin{array}{l}\text { IWUE } \\
\left(\mathrm{kg} / \mathrm{m}^{3}\right)\end{array}$ & $\begin{array}{l}\text { Irrigation } \\
\text { Treatment }\end{array}$ & Yield $\left(\mathrm{t} \mathrm{ha}^{-1}\right)$ & WUE $\left(\mathrm{kg} / \mathrm{m}^{3}\right)$ & $\begin{array}{l}\text { IWUE } \\
\left(\mathrm{kg} / \mathrm{m}^{3}\right)\end{array}$ \\
\hline $\mathrm{V}_{100} \mathrm{~F}_{100} \mathrm{Y}_{100} \mathrm{R}_{100}$ & 92,2 & 0,13 & 0,17 & $\mathrm{~V}_{100} \mathrm{~F}_{100} \mathrm{Y}_{100} \mathrm{R}_{100}$ & 93,4 & 0,13 & 0,17 \\
\hline V75FYR & 88,6 & 0,13 & 0,17 & V75FYR & 90,1 & 0,13 & 0,17 \\
\hline V50FYR & 86,4 & 0,14 & 0,16 & V50FYR & 87,9 & 0,13 & 0,17 \\
\hline $\mathrm{V}_{25} \mathrm{FYR}$ & 83 & 0,13 & 0,16 & V25FYR & 85,3 & 0,13 & 0,16 \\
\hline VF75YR & 83,8 & 0,12 & 0,15 & VF75YR & 80,5 & 0,12 & 0,16 \\
\hline VF50YR & 83,6 & 0,12 & 0,16 & VF50YR & 78,6 & 0,12 & 0,16 \\
\hline $\mathrm{VF}_{25} \mathrm{YR}$ & 82,5 & 0,12 & 0,15 & $\mathrm{VF}_{25} \mathrm{YR}$ & 73,2 & 0,11 & 0,16 \\
\hline VFY75R & 85,8 & 0,13 & 0,16 & VFY75R & 83,8 & 0,12 & 0,16 \\
\hline $\mathrm{VFY}_{50 R}$ & 84,6 & 0,13 & 0,16 & $\mathrm{VFY}_{50 R}$ & 82,8 & 0,13 & 0,16 \\
\hline$V_{F} Y_{25 R}$ & 82,8 & 0,13 & 0,16 & VFY25R & 80,9 & 0,13 & 0,16 \\
\hline VFYR75 & 86,7 & 0,14 & 0,17 & VFYR75 & 90,6 & 0,13 & 0,16 \\
\hline VFYR50 & 84,4 & 0,13 & 0,16 & VFYR50 & 89,2 & 0,13 & 0,17 \\
\hline VFYR25 & 82,7 & 0,14 & 0,16 & VFYR25 & 85,8 & 0,13 & 0,17 \\
\hline VoFoYoRo & 2,00 & 0,01 & 0,00 & VoFoYoRo & 4,0 & 0,01 & 0,00 \\
\hline
\end{tabular}

\section{Discussion}

In this experiment, irrigation treatments considerably influenced yield, fruit weight, diameter, height and dry matter. In both experimental years, the maximum amounts of water applied to the crop were 554-556 mm for from $\mathrm{V}_{100} \mathrm{~F}_{100} \mathrm{Y}_{100} \mathrm{R}_{100}$ while the seasonal evapotranspiration (ETa) values were changed between 725-300 and 746$340 \mathrm{~mm}$ for $\mathrm{V}_{0} \mathrm{~F}_{0} \mathrm{Y}_{0} \mathrm{R}_{0}$ treatment. Total water amounts varied from 400 to $600 \mathrm{~mm}$ depending upon climate and length of growing season (Doorenbos and Kassam, 1979). Water applied for tomato ranged from 415 to $800 \mathrm{~mm}$ under different controlling sistems (Mahajan and Singh, 2006). Ayas (2015) stated that irrigation water amount applied for tomato varied from 65 to $564 \mathrm{~mm}$ in different treatments in the province of Bursa of Turkey. Kirda et al. (2004) reported that total seasonal evapotranspiration by tomato for spring and fall planted varied from 274 to $447 \mathrm{~mm}$ and irrigation water applied varied from 173 to $456 \mathrm{~mm}$. Hanson and May (2011) determined that applied water ranged from 582 to $1018 \mathrm{~mm}$. Berihun (2011) also reported that two days irrigation interval was used and a factorial combination of three levels of water (namely 315, 440 and $565 \mathrm{~mm}$ ) combined with three mulch treatments. Wan et al. (2007) specified that for three years, evapotranspiration of tomato was $607 \mathrm{~mm} / \mathrm{season}$ for drip irrigation with saline water. Seasonal evapotranspiration varied from 405 to $946 \mathrm{~mm}$ and irrigation amount applied from 271 to $832 \mathrm{~mm}$ in the province of Eskişehir in 
Turkey between 1998 and 2000 years (Cetin et al., 2002). These results are notably in accordance with the irrigation water amounts and crop water consumption values obtained from previous studies (Kuscu et al., 2014; Ayas, 2015; Gatta et al., 2015; Biswas et al., 2015; Linker et al., 2016).

The tomato yield ranged between 92.2-2.0 and 93.4-4.0 t ha- ${ }^{-1}$ for 2009 and 2010 years, respectively. Yield was decreased as the irrigation water amount reduced. As a result, the effect of deficit irrigation was found significant on total yield. This result was compatible with those of (Liu et al., 2013; Kuscu et al., 2014; Saadi et al., 2015; Ayas, 2015; Gatta et al., 2015; Biswas et al., 2015; Nangare et al., 2016). As in yield, some quality parameters of tomato (fruit weight, diameter, height and dry matter) showed a similar response to deficit irrigation.

As for fruit weight, there was influence of deficiency irrigation on single fruit weight with respect to quality parameters. As observed in yield, the fruit diameter and weight gave similar response to deficit irrigation. The highest quality parameters were obtained from $\mathrm{E}_{100} \mathrm{~V}_{100} \mathrm{Y}_{100} \mathrm{R}_{100}$ treatments every two experiment years. The non-irrigated $\left(\mathrm{V}_{0} \mathrm{~F}_{0} \mathrm{Y}_{0} \mathrm{R}_{0}\right)$ treatment had lower values than all irrigation treatments. The result of study were in conformance with (Akhtar et al., 2014; Kuscu et al., 2014; Ayas, 2015; Biswas et al., 2015; Nangare et al., 2016). Since $\mathrm{V}_{100} \mathrm{~F}_{100} \mathrm{Y}_{100} \mathrm{R}_{100}$ treatments had higher fruit weight than the other treatments, the lowest dry matters have been found at $\mathrm{V}_{100} \mathrm{~F}_{100} \mathrm{Y}_{100} \mathrm{R}_{100}$ treatments when the highest dry matter values were observed at $\mathrm{E}_{0} \mathrm{~V}_{0} \mathrm{Y}_{0} \mathrm{R}_{0}$ treatments in both years of the experiment. As a result, we may say that as the amount of irrigation water decrease, the number of dry matter increases. These values are similar to those of previous studies (Birhanu and Tilahun, 2010; Ayas, 2015; Gatta et al., 2015; Candido et al., 2015).

The maximum WUE and IWUE values were found as 0.14-0.19 and 0.14-0.19 for 2009 and 2010 years, respectively. The maximal WUE and IWUE values were obtained in vegetative and ripening periods and the lowest value was obtained from flowering and yield formation periods. When the results concerning WUE values were in comparison to the findings of different researchers, they were in agreement with those of the other studies (Alomran et al., 2012; Mukherjee et al., 2012; Kuscu et al., 2014; Ayas, 2015; Cantore et al., 2016).

The variety of tomato, climate of the region, soil properties and effective use of water also influence yield and quality parameters of tomato. As explained by Davis et al. (2008), it may be attributed to the variety and applied cultural practices handling under different climate and geographical conditions. Crop yield response factor $\left(\mathrm{k}_{\mathrm{y}}\right)$ for 2009 and 2010 year were calculated as 1.05 and 1.06 for tomato, respectively. The specified values of $\mathrm{k}_{\mathrm{y}}(1.05-1.06)$ which is bigger than 1.00 shows that tomato is responsive to the water. The factor of $\mathrm{k}_{\mathrm{y}}$ also matches up with the values obtained by researchers who studied on similar issues (Doorenbos and Kassam, 1979; Kuscu et al., 2014; Ayas, 2015; Cantore et al., 2016).

\section{Conclusion}

According to the results of the study, irrigation water were applied 554 and $556 \mathrm{~mm}$ in $\mathrm{V}_{100} \mathrm{~F}_{100} \mathrm{Y}_{100} \mathrm{R}_{100}$ treatment applied of full irrigation in 2009 and 2010 years. The plant water consumption of tomato was determined as $300-725 \mathrm{~mm}$ and $340-746 \mathrm{~mm}$ for $\mathrm{V}_{0} \mathrm{~F}_{0} \mathrm{Y}_{0} \mathrm{R}_{0}$ treatment 2009 and 2010 years. The factors of $\mathrm{k}_{\mathrm{y}}$ for the different irrigation levels $\left(V_{100} F_{100} Y_{100} R_{100}, V_{75} F Y R, V_{50} F Y R, V_{25} F Y R, V F_{75} Y R, V F_{50} Y R, V F_{25} Y R, V F Y_{75} R\right.$, 
$V F Y_{50} R, V F Y_{25} R, V F Y R_{75}, V F Y R_{50}, V F Y R_{25}, V_{0} F_{0} Y_{0} R_{0}$ treatments) in 2009 and 2010 years were calculated as 1.05 and 1.06 for tomato, respectively. The factors of $\mathrm{k}_{\mathrm{y}}(1.05$ and 1.06) values are bigger than 1.00 showed that the tomato was susceptible to water. The crop yield response factors $\left(\mathrm{k}_{\mathrm{y}}\right)$ were close to each other in both years of the study. The highest yield decreases in all treatments were in $V_{0} F_{0} Y_{0} R_{0}$ treatments, while the lowest yield decreases were in $V_{100} F_{100} Y_{100} R_{100}$ treatments. In our trial, it was studied out that irrigation treatments considerable influences yield, fruit diameter, weight, height and dry matter ratio.

In this study, it was studied out that irrigation applications considerably influences yield, fruit weight, diameter, height and dry matter. In both years of the study, the highest yield was $92.2 \mathrm{t} \mathrm{h}^{-1}$ and $93.4 \mathrm{t} \mathrm{h}^{-1}$ and it was observed in $\mathrm{V}_{100} \mathrm{~F}_{100} \mathrm{Y}_{100} \mathrm{R}_{100}$ treatment. The lowest yield was observed as $2.0 \mathrm{t} \mathrm{h}^{-1}$ and $4.0 \mathrm{t} \mathrm{h}^{-1}$ in $\mathrm{V}_{0} \mathrm{~F}_{0} \mathrm{Y}_{0} \mathrm{R}_{0}$ treatment. Yield decreased considerably as a result of the diminishment in the water amount. Relative yield decreases in the irrigation treatments in 2009 and 2010 were $4.1 \%, 6.7 \%, 11.1 \%, 10.0 \%, 10.3 \%, 11.8 \%, 7.5 \%, 9.0 \%, 11.4 \%, 6.3 \%, 9.2 \%, 11.5 \%$, $4510.0 \%$ and $3.7 \%, 6.3 \%, 9.5 \%, 16.0 \%, 18.8 \%, 27.6 \%, 11.5 \%, 12.8 \%, 15.5 \%, 3.1 \%$, $4.7 \%, 8.9 \%, 2235.0 \%$, respectively. WUE and IWUE values of vegetative and ripening periods were the maximum of all the treatments.

As a result of a possible deficit irrigation in a semi-humid climate condition, it is necessary to plan carefully and it is possible to say that the levels and times of the deficit irrigation were significantly effective on tomato yield. If deficit irrigation treatment is obligatory, water deficiency should be planned only for vegetative and ripening periods of tomato. The water deficiency should not be applied in flowering and yield formation periods and irrigations in these periods should be exactly applied. In addition, in the irrigation planning to be applied in similar climatic conditions may be benefited from crop yield response factor (ky) values. The results used to determine the amount of reduction in yield in response to the water deficiency applied to the plant may be used in studies related to tomato. It can be recommended that vegetative and ripening periods is most suitable periods for the deficit irrigation practices for tomato irrigation by drip irrigation.

\section{REFERENCES}

[1] Akhtar, S. S., Li, G., Andersen, M. N., Liu, F. (2014): Biochar enhances yield and quality of tomato under reduced irrigation. - Agric. Water Management 138: 37-44.

[2] Alomran, A. M., Al-Harbi, A. A. R., Wahb-Allah, M. A., Alwabel, M. A., Nadeem, M. E. A., Al-Eter, A. (2012): Management of irrigation water salinity in greenhouse tomato production under calcareous sandy soil and drip irrigation. - J. Agr. Sci. Tech. 14: 939950.

[3] Anonymous (2005): The Annual Report of Meteorological Station, Bursa, Turkey. www.mgm.gov.tr/verideğerlendirme/il-ve-ilceler-istatistic.aspx?k

[4] Anonymous (2011a): The Annual Report of Meteorological Station, Bursa, Turkey. www.mgm.gov.tr/verideğerlendirme/il-ve-ilceler-istatistic.aspx?k

[5] Anonymous (2011b): The Meteorological Station of Greenhouse Application Area, Yenişehir-Bursa, Turkey. Www.mgm.gov.tr/verideğerlendirme/il-ve-ilceleristatistic.aspx?k

[6] Ashraf, S. O. and Ewees, M. S. A. (2008): The possible use of humic acid incorporated with drip irrigation system to alleviate the harmful effects of saline water on tomato plants. - Fayoum J. Agric. Res. \& Dev. 22(1). 
[7] Ayas, S. (2015): The effects of different regimes on tomato (Lycopersicon lycopersicum L. Var. Hazal) yield and quality characteristics under unheated greenhouse conditions. Bulgarian Journal of Agricultural Science 21(6): 1235-1241.

[8] Bar-Yosef, B., Sagiv, B. (1982): Response of tomatoes to N and water applied via a trickle irrigation system. - II Water. Argon. J. 74: 637-639.

[9] Berihun, B. (2011): Effect of mulching and amount of water on the yield of tomato under drip irrigation. Journal of Horticulture and Forestry 3(7): 200-206.

[10] Birhanu, K., Tilahun, K. (2010): Fruit yield and quality of dripirrigated tomato under deficit irrigation. - African Journal of Food, Agriculture, Nutrition and Development 10(2): 1684-5358.

[11] Bogle, C. R., Hartz, T. K., Nuntoez, C. (1989): Comparison of subsurface trickle and furrow irrigation on plastic mulched and bare soil for tomato production. - J. Am. Soc. Hortic. Sci. 114: 40-43.

[12] Bos, M. G. (1980): Irrigation efficiencies at crop production level. - ICID Bull.29: 18-25.

[13] Büyükcangaz, H., Demirtas C, Yazgan S, Korukcu, A. 2007. Efficient water use in agriculture in Turkey: The need for pressurized irrigation systems. - Water International 32(suppl 1): 776-785.

[14] Cakmak, B., Gokalp, Z. (2011): Climate change and effective water utilization. - Journal of Agricultural Sciences Research 4(1): 87-95.

[15] Candido, V., Campanelli, G., D’Addabbo, T., Castronuova, D., Perniola, M., Camele, I. (2015): Growth and yield promoting effect of artificial mycorrhization on field tomato at different irrigation regimes. - Scientia Horticulturae 187: 35-43.

[16] Cantore, V., Lechkar, O., Karabulut, E., Sellami, M. H., Albrizio, R., Boari, F., Stellaci, A. M., Todorovic, M. (2016): Combined effect of deficit irrigation and strobilurin application on yield, fruit quality and water use efficiency of "cherry" tomato (Solanum lycopersicum L.). - Agric. Water Management 167: 53-61.

[17] Cetin, Ö., Yıldırım, O., Uygan, D., Boyac1, H. (2002): Irrigation scheduling of dripirrigated tomatoes using class a pan evaporation. - Turkish Journal of Agriculture and Forestry 26: 171-178.

[18] Clough, G. H., Locasio, S. J., Olsen, S. M. (1990): The yield of successively cropped polyethylene mulched vegetables as affected by irrigation method and fertilization management. - J. Am. Soc. Hortic. Sci. 115: 884-887.

[19] Davis, A. R., Webber, C. L., Perkins-Veazie, P., Ruso, V., Lopez Galarza, S., Sakata, Y. (2008): A Review of Production Systems on Watermelon Quality. - In: Pitrat, M. (ed.) Proceedings of the IXth EUCARPIA Meeting on 98 Genetics and Breeding of Cucurbitaceae, INRA, Avignon, France, pp. 515-520.

[20] Doorenbos, J., Kassam, A. H. (1979): Yield Response to Water. - FAO Irrigation and Drainage Paper No. 33, Rome.

[21] FAOSTAT (2017): Food and Agriculture Organization Corporate Statistical Database. http://www.fao.org/faostat/en/\#data/QC.

[22] Gatta, G., Libutti, A., Gagliardi, A., Beneduce, L., Brusetti, L., Borruso, L., Disciglio, G., Tarantino, E. (2015): Treated agro-industrial wastewater irrigation of tomato crop: Effects on qualitative/quantitative characteristics of production and microbiological properties of the soil. - Agric. Water Management 149: 33-43.

[23] Hanson, B., May, D. (2011): Crop evapotranspiration of processing tomato in the San Joaquin Valley of California, USA. - Irrigation Science 24: 211.

[24] Hartz, T. K. (1993): Drip irrigation scheduling for fresh market tomato production. Hort. Science 28: 35-37.

[25] Kirda, C., Çetin, M., Dasgan, Y., Topçu, S., Kaman, H., Ekici, B., Derici, M. R., Özgüven, A. İ. (2004): Yield response of greenhouse grown tomato to partial root drying and conventional deficit irrigation. - Agric. Water Management 69: 191-201. 
[26] Kuscu, H., Turhan, A., Demir, A. O. (2014): The response of processing tomato to deficit irrigation at various phenological stages in a sub-humid environment. - Agric. Water Management 133: 92-103.

[27] Linker, R., Loslovich, I., Sylaios, G., Plauborg, F., Battilani, A. (2016): Optimal modelbased deficit irrigation scheduling using Aqua Crop: a simulation study with cotton, potato and tomato. - Agric. Water Management 163: 236-243.

[28] Liu, H., Duan, A. W., Li, F. S., Sun, J. S., Wang, Y. C., Sun, C. T. (2013): Drip irrigation scheduling for tomato grown in solar greenhouse based on pan evaporation in North China Plain. - Journal of Integrative Agriculture 12(3): 520-531.

[29] Mahajan, G., Singh, K. G. (2006): Response of greenhouse tomato to irrigation and fertigation. - Agric. Water Management 84: 202-206.

[30] McNeish, C. M., Welch, N. C., Nelson, R. D. (1985): Trickle irrigation requirements for stawberries in coastal California. - J. Am. Soc. Hortic. Sci. 110: 714-718.

[31] Mukherjee, A., Sarkar, S., Chakraborty, P. K. (2012): Marginal analysis of water productivity function of tomato crop grown under different irrigation regimes and mulch managements. - Agric. Water Management 104: 121-127.

[32] Nangare, D. D., Singh, Y., Kumar, P. S., Minhas, P. S. (2016): Growth, fruit yield and quality of tomato (Lycopersicon esculentum Mill.) as affected by deficit irrigation regulated on phenological basis. - Agric. Water Management 171: 73-79.

[33] Papadopoulos, L. (1992): Fertigation of vegetables in plastic house: present situation and future aspects. - Acta Horticulturae 323: 151-174.

[34] Ritchie, J. T., Johnson, B. S. (1990): Irrigation of agricultural crops. - Agronomy Monograph 30: 363-390.

[35] Saadi, S., Todorovic, M., Tanasijevic, L., Pereira, L. S., Pizzigalli, C., Lionello, P. (2015): Climate change and Mediterranean agriculture: Impacts on winter wheat and tomato crop evapotranspiration, irrigation requirements and yield. - Agricultural Water Management 147: 103-115.

[36] Sezen, S. M. (2005): Effects of drip irrigation management on yield and quality of field grown green beans. - Agricultural Water Management 71: 243-255.

[37] Steel, R. G. D., Torrie, J. H. (1980): Principles and Procedures of Statistics. A Biometrical Approach. - McGraw-Hill, NewYork, pp.186-187.

[38] Stewart, J. I., Misra, R. D., Pruitt, W. O., Hagan, R. M. (1975): Irrigating corn and sorghum with a deficient water supply. - Trans. ASAE 18: 270-280.

[39] Van Straten, G., Van Willingenburg, G., Van Henten, E., Van Ooteghem, R. (2010): Optimum Control of Greenhouse Cultivation. - CRC Press, USA.

[40] Wan, S., Kang, Y., Wang, D., Liu, S. P., Feng, L. P. (2007): Effect of drip irrigation with saline water on tomato yield and water use in semi-humid area. - Agric. Water Management 90: 63-74.

[41] Yuan, B. Z., Sun, J., Nishiyama, S. (2003): Effect of drip irrigation on strawberry growth inside a plastic greenhouse. - Biosystems Engineering 87(2): 237-245.

[42] Zhang, H., Wang, X., You, M., Liu, C. (1999): Water-yield relations and water-use efficiency of winter wheat in the North China Plain. - Irrigation Science 19: 37-45. 